\title{
Gonfienti (Prato, Tuscany, Central Italy), a zooarchaeological snapshot on daily sixth-century Etruscan household life
}

\author{
Chiara Capalbo ${ }^{1}$ (D) Giulia Peri $^{2}$ (D) Paul P. A. Mazza ${ }^{1}$ (D)
}

Received: 10 June 2021 / Accepted: 23 August 2021 / Published online: 21 September 2021

(c) The Author(s) 2021

\begin{abstract}
While Etruscan sites have received considerable attention over the years, scholarly focus has rarely been directed on the faunal remains from the various celebrated archaeological localities. The present is a zooarchaeological analysis of archaeofaunal material from Gonfienti, a renowned Etruscan locality near Prato, in north-central Tuscany. The vast, complex archaeological site includes a large building, called Edifice 1, that was constructed starting from the sixth century BC. Predominant taphonomic signatures, human-induced damage, archaeobiological evidence and mortality patterns obtained from the study of the faunal remains from the building's main phase of occupation revealed that the householders depended principally on cattle and subordinately on domestic suids for much of their subsistence, although game also formed part of the diet. The zooarchaeological interpretations match up very well with the interpretations of the excavators and archaeologists concerning the function of Edifice 1 and the use of some of its rooms. In addition, the low incidence of in situ weathering, extensive corrosion of cortical bone surfaces possibly by exposure to alkaline solutions and the relatively high frequency of waterfowls in the studied samples suggest that the area hosting Edifice 1 experienced very humid conditions and was surrounded by large wetland expanses at the time of its main Etruscan occupation.
\end{abstract}

Keywords Gonfienti $\cdot$ Central Italy $\cdot$ Etruscan civilization $\cdot$ Zooarchaeology $\cdot$ Subsistence strategies

\section{Introduction}

During the mid-1990s of the last century, public works for the construction of the Central Tuscany Interport and the new Florence-Prato road infrastructure, in the proximity of Prato and some $10 \mathrm{~km}$ NE of Florence, brought to light several remains of the ancient Etruscan city of Gonfienti (Poggesi et al. 2005; Fig. 1). The first 1996 report on the archaeological investigations was followed by many new surveys to verify the extent and possible amount of archaeological evidence present in the area (Bocci and Poggesi 2000). These surveys led to the location of remains of the walls of a vast Etruscan housing complex unknown until then.

The settlement is located on a gently sloping, southwestfacing foothill, near the Bisenzio River. The whole area is

Paul P. A. Mazza

paul.mazza@unifi.it

1 Department of Earth Sciences, University of Florence, Florence, Italy

2 Department of History, Archaeology, Geography, Art and Entertainment (Sagas), Florence, Italy waterlogged by surface water or groundwater from north; the site lies just above the water table which, in the winter period, rises to a few centimetres from the ground surface. This causes generalized flooding; the Etruscans already attempted to control waterlogging by constructing a dense network of surface drains (Poggesi et al. 2006).

In the 2000s, excavations have been regularly conducted until 2009. These activities led to the identification of five distinct sectors, called Lot 14, Lot 15F and Compensation Basin. Regular housing units, bounded by streets and deep channels, were unearthed in both Lot $15 \mathrm{~F}$ and Compensation Basin (Poggesi et al. 2005; Perazzi et al. 2011). A large building ( $43^{\circ} 51^{\prime} 20.9^{\prime \prime} \mathrm{N}, 11^{\circ} 7^{\prime} 58.3^{\prime \prime} \mathrm{E}$, source: Google Maps, 2021) was found in Lot 14 (Poggesi, 2013), which is the best investigated area situated close to a road running at right angle to Lot $15 \mathrm{~F}$, with the internal structural features typical of the Etrusco-Italic atrium houses (Fig. 1). The building of Lot 14 was called Edifice 1 and confidently dated thanks to the variety of items found in it, as well as to the detailed analysis of its structural characters. In particular, the earliest habitation levels in the site's south-eastern sector date back to around the middle sixth century BC. 
Fig. 1 Location of the Etruscan City of Gonfienti (A), aerial view of Gonfienti's Edifice 1 (B) and Edifice 1's plan (C), with indication of the various rooms on the eastern (E1-3), southern (S1-3), western (W13 ) and northern (N1-11) wings of the building

Edifice 1 was constructed atop these early structures and was inhabited until the end of the fifth century $\mathrm{BC}$, when climate changes possibly rendered the canalization obsolete and unable to regulate the water supply in the area, ultimately transforming the Gonfienti area into a wetland. The area was abandoned for centuries, as the population probably moved to the hills in the surroundings. In the Early Imperial period, the Gonfienti area was inhabited again, constructions were rebuilt, and a small industrial area and burials were added (Poggesi et al. 2005).

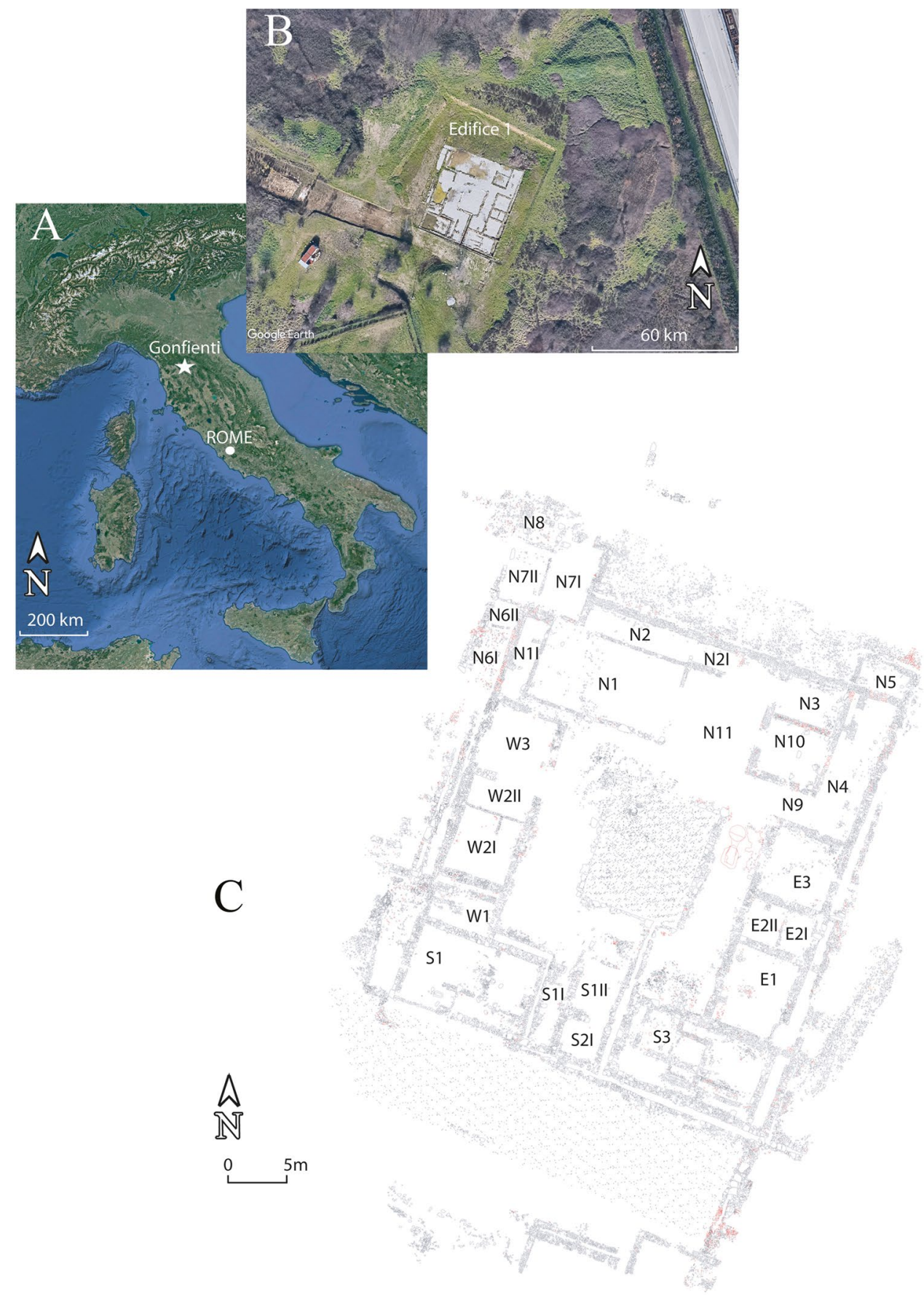

\section{Lot 14 and Edifice 1}

The large Edifice 1 of Lot 14, which was built and used in the sixth century BC, was about $1400 \mathrm{~m}^{2}$ wide, irregularly rectangular and oriented NE-SW. Its rooms were arranged around a central, open, square internal courtyard and were covered by an inward sloped roof (compluvium). The courtyard floor is slightly convex at the centre, paved with light gravel and bordered on all sides by a portico 
with a colonnade and revealed by a series of plinths (Poggesi et al. 2005). A ditch was made along the southern side of the construction to drain the water from the inner courtyard into the channelling that ran along the perimeter of the building (Poggesi et al. 2005). Roof tile fragments are scattered throughout the whole area around Edifice 1 , but the highest concentration was found in the courtyard (Poggesi et al. 2005). A circular well was found near the northwest corner of the covered part of the courtyard; the artefact is bounded by a raised edge to prevent water contamination. The entrance was on the southern side; it opened onto a road directed NW-SE but with a deep channel between the road and the building. Two large rectangular chambers S1 and S3, located symmetrically on the two sides of a room, S2, thought to act as vestibule to the central courtyard, did not seem to serve any residential function but rather were somehow related to the street they opened on to. In addition, a series of medium-sized rooms overlooked the east and west side of the portico (Millemaci and Pagnini 2011).

Three rooms have been identified on the western side of Edifice 1: W1, W2 and W3. Many fragments of kitchenware were found in $\mathrm{W} 1$ distinguishing it as a kitchen compartment, while two large dolii were found in the adjacent room W2. The dolii were often used to contain foodstuffs, and the proximity to the kitchen suggests that $\mathrm{W} 2$ functioned as a pantry. The third chamber, W3, was filled with roofing material. Excavations conducted in 2006 brought to light structures of earlier construction phases, placed under the floor of rooms W1 and W2.

Other three rooms, E1, E2 and E3, were found on the eastern side of Edifice 1. A bell-shaped oven was unearthed under the floor of room E1. A cooking pot, overturned on its handle and covered by baked clay, was found preserved in a small hole in room E2, close to the northeastern wall; the hypothesis is that it may be associated with a domestic cult practice (Poggesi et al. 2011).

The greatest interpretive challenges are posed by the northern area, which is the part of Edifice 1 that has undergone the most extensive alterations over time. This area was refurbished and partially transformed already in the Etruscan period, probably in connection with the creation of a first drainage water management system, and then again in the Roman period. These structural modifications partially affected the original layout of the building: rooms N6, N7 and N8, in Edifice 1's northwest wing, do not harmonize well with the original structures but rather protrude from the perimeter wall (Perazzi et al. 2011). Room N7 is almost square and had been divided into two smaller chambers; room N8 seems to have been added subsequently. Two other rooms in the northeastern sector, N3.I and N3.II, are surrounded on three sides, to the south, east and west, by a large corridor. A small trapezoidal compartment, N5, is preserved further east; it too, like the rooms on the northwest wing, steps forward from the perimeter wall of Edifice 1 as an avant-corps. Remains of charred wood, probably from a pillar, were preserved in N5. A hollow, truncated horn handle made in bucchero, with human figure depicted on it and associated with wild boar tooth, was found at the partition wall with room N4 (Poggesi et al. 2007). Finally, rooms N5 and N7 formed a wide, paved outdoor space of still unknown use and extension (Perazzi et al. 2011).

The series of excavations undertaken at Gonfienti over the years unearthed a considerable amount of archaeofaunal remains from many different time periods. The present zooarchaeological analysis focuses on the faunal material found within Edifice 1, in Gonfienti's Lot 14. More precisely, the specimens considered for this study are the ones from the rooms of the northern $(\mathrm{N} 1, \mathrm{~N} 2, \mathrm{~N} 3, \mathrm{~N} 5, \mathrm{~N} 6$, N10), southern (S1, S1.I, S1.II, S2.II), eastern (E1, E2, E2.II, E3) and western wings (W1 e W2) of the building and from the level that archaeologists call phase 4, which deposited at the time when Edifice 1 flourished and was at its grandest.

\section{Methods}

The archaeobiological and taphonomic analyses started with the anatomical and taxonomic identification of the remains, by side, skeletal portion (e.g. proximal-distal epiphysis, diaphysis, medial, lateral, cranial/dorsal, caudal/ventral) and by class, genus and species, with use of manuals and by direct comparison with specimens from the collection Borzatti von Löwerstern of the Natural History Museum of the University of Florence. All specimens (identified and unidentified) were categorized and counted by size in small $(<2.5 \mathrm{~cm})$, medium $(2.5-5 \mathrm{~cm})$ and large $(>5 \mathrm{~cm})$. This analysis permitted to calculate quantitative units classically used for taphonomic and zooarchaeological purposes (Lyman 1994; Reitz and Wing 2010): NISP (number of identified specimens), MNI (minimum number of individuals) and MNE (minimum number of elements). The NISP was used here both as observational unit, thereby as primary data, and as derived unit, to estimate the relative frequencies of the taxa represented in the site, thus as secondary data. The MNI and MNE are derived units, and thereby secondary data, which take into account individual variation such as age, sex, size, skeletal proportion, degree of ossification and state of conservation. The MNI was obtained by counting the minimum number of specimens referable to given individuals and the MNE by determining the minimum number of specimens that could be referred to given elements. 


\section{Skeletal representation and bone modification}

Skeletal representation was assessed by comparing MNEbased observed frequencies with MNI-based expected ones. The morphological features of the bone fractures were recorded following Haynes' (1983) and Villa and Mahieu's (1991) indications to determine whether elements were broken in fresh-green or old-dry state.

Pre- and post-depositional cortical bone modifications were analysed with the aid of $10-20 \times$ lenses. Pre-burial modifications are a repository of primary data recording the events bones were exposed to before final deposition. These include alterations of both biotic (e.g. fungal/bacterial corrosion, scavenger ravaging, signatures of human intentional activities, trampling, root etching, pathologic modifications) and abiotic origin (e.g. weathering, chemical corrosion, abrasion/polishing). In particular, possible patterns of human-induced disturbance (carcass dismembering, butchering, cooking, etc.) were sought for in cases where evidence suggested that bones were broken while still fresh; the ultimate aim of these investigations was gaining insights into the strategies of exploitation of animal carcasses and thereby into the procurement strategies and social status of Edifice 1's householders. More specifically, major human-related modifications located around long bone diaphysis and phalanges were considered indicative of flaying and butchery actions (Braun et al. 2008; Cilli et al. 2000); sharp force trauma, or cutting on epiphyseal ends, vertebrae, etc., signs of dismemberment; long and deep furrows were related to de-boning (Binford 1981). Modifications by manufacturing and polishing by use, as well as thermal alteration related to cooking practices, are other kinds of human-derived damage typically expected in a settlement context (Shipman et al. 1984; Shipman 1988; Binford 1981; David 1990; Karkanas et al. 2007). All these possible modifications were tallied by skeletal element and their incidence expressed in terms of NISP counts.

\section{Carcass exploitation}

Because of its provenance from a human settlement, the remains of the Edifice 1 archaeofaunal assemblage were subjected to tests which aimed at verifying their possible exploitation for food. The general purpose of these studies was to gain insights into the economic and social life of the Etruscan population that inhabited the Gonfienti area. In this regard, the frequency of the limb elements represented at the site were correlated with Binford's (1978) modified general utility index (MGUI) counts, as well as with Metcalfe and Jones' (1988) standardized food utility index (sFUI) values. These indexes measure the utility, or food value, of the soft tissues associated with or attached to the various skeletal elements in carcasses of different taxa; they are practically based on subsidiary indices that incorporate various components of utility, such as meat, marrow, bone grease utility and general utility. MGUI and sFUI values for the elements of various taxa can be found in specialized literature (Binford 1981; Lyman 1994; Rowley-Cowney et al. 2002). Because the utility associated with the different bone elements is normally inversely correlated with the density of those same elements, the two taphonomic variables are not independent. For this reason, MGUI/sFUI counts were here crossed with the structural density values for the correspondent skeletal elements, in the assumption that significantly high amounts of dense bones with low MGUI/sFUI counts are likely butchery discards and, conversely, significantly abundant porous bones with higher utility are meal waste. Also bone density values for various taxa are available from the literature (e.g. Ioannidou 2003; Symmons 2005). The statistical significance of the correlations was evaluated by calculating the Spearman correlation coefficient rs.

\section{Archaeobiological information}

Other procedures were aimed at obtaining specific biological information about the fauna from Edifice 1, in particular regarding ontogenetic age and sex of the individuals represented in the assemblage. Ontogenetic ages were estimated based on the degree of long bone epiphyseal fusion, as well as on the degree of emergence and wear of teeth. Although osteological maturity varies individually with sex, health and nutritional status, the timing and sequence of epiphyseal fusion and of tooth emergence are under genetic control and thereby relatively constant among mammals; they can thus be used with fair confidence to establish age classes. Proximal or distal limb bone ends fuse at different ontogenetic stages; there are early, intermediate or late fusing epiphyses. The degree of ossification increases accordingly. Conversely, dental wear is strongly dependent on the toughness of the food that was consumed but also, and perhaps more importantly, on the amount of abrasive grit in the diet. Dental wear can therefore provide useful information on the quality of the food ingested and on the environmental context of life.

The number of dead individuals per age class was tallied for each of the best represented taxa in the Edifice 1 assemblage and plotted in histograms, with age class bars scaled to the frequency of individuals per age class. The resulting age-frequency distributions depict the mortality patterns of the faunal components that are best represented in the assemblage.

The mortality profiles for bovids were constructed following Grant's (1982) tooth eruption and wear scheme, together with Hambleton's (2001) conversion of Grant's wear stages, which is based on the revision of Payne's (1973) wear stages of the deciduous fourth premolar and of the molars. The demographics of mortality of the suids were reconstructed 
following Lemoine et al. (2014). Finally, when possible, attempts were made to sex the remains. Sex is basic to interpretations related to food preferences and husbandry strategies. In the case of suids, given the bad state of preservation of the skulls, sexes could only be discriminated based on the shape and size of the canines.

Each specimen was listed in a Microsoft Excel 365 computer database, accompanied by all the primary, descriptive and observational information that could be extracted from it. This was basic to the elaboration of inferential secondary data, e.g. relative skeletal frequencies, frequencies of taxa, age classes, sex ratios and estimates of dietary contributions. For analysis, the assemblage data for each room sample are presented individually in Supplementary Table 1, but were unified into a single assemblage, rather than reported as subassemblages. A special focus is directed only on results of particular interest relative to the fauna from specific rooms.

\section{Results}

A total of 1364 bones were retrieved from Gonfienti's Edifice 1 . The majority, $72.87 \%$, was identified both anatomically and taxonomically; 7 specimens were identified only anatomically and 6 only taxonomically. Indeterminate specimens sum up to $357: 81.51 \%$ of them are smaller than $2.5 \mathrm{~cm}, 15.97 \%$ are between 2.5 and $5 \mathrm{~cm}$ and only $1.96 \%$ are larger than $5 \mathrm{~cm}$. Faunal lists, as well as relative quantifications in terms of NISP, MNE and MNI counts, for Edifice 1's individual rooms are summarized in Table 1 and detailed in Supplementary Table 1. The skeletal remains were unevenly distributed throughout the various rooms: $28.37 \%$ of them come from $\mathrm{E} 1 ; 14.37 \%$ was found in $\mathrm{S} 1 ; \mathrm{N} 1$ provided $12.17 \%$. The rooms $\mathrm{W} 2$, E3 and $\mathrm{W} 1$ yielded $8.43 \%$, $8.21 \%$ and $7.11 \%$ of the analysed sample, respectively. Domestic fauna is dominant. The bulk of the assemblage is formed by Bovidae (51.71\%). The family includes four species, i.e. two different sized Bovinae, a larger (22.53\%) and a smaller Bos taurus (2.01\%) and Caprinae (sheep and goats: $23.34 \%$ ). Bovids are followed, in relative abundance, by Suidae (45.97\%). The domesticates also include Canis lupus familiaris. Wild taxa are represented by wild boar, Sus scrofa; red deer, Cervus elaphus; and hare (Lepus sp.), with also rare remains of brown bear, Ursus arctos, and badger, Meles meles. Regarding non-mammal components, the assemblage is completed by rare occurrences of birds, including three species typical of wetlands (Anas platyrhynchos, Gavia arctica and Limosa limosa) and possibly also the domestic fowl (Gallus gallus domesticus), two specimens of European pond turtle, Emys orbicularis, and a fragment of shellfish. Worth mentioning is the presence of two human remains and of a worked bone artefact (Fig. 2). The former are two fragmental parietal bones, found in the room S2.II, of a juvenile individual and a humerus from E1 of a fullterm foetus (Fig. 2). Figure 3A-C shows the overall skeletal frequencies of the most representative taxa of Edifice 1; examples of the taphonomic modifications observed on the bones are shown in Fig. 4.

\section{Skeletal representation and bone modification}

The comparison of observed and expected frequencies reveals a clear under-representation of all skeletal elements, but particular scarcity of the elements of the axial skeleton, basipodial bones and phalanges, despite careful sieving of the excavated sediments at $1 \mathrm{~mm}$; girdle, stylopodial, zeugopodial elements and, subordinately, mandibles and metapodials are somewhat better represented.

Both pre- (biostratinomic) and post-depositional (diagenetic) alterations have been detected; the former include clear evidence of human intervention. Fracture morphologies indicate fragmentation in both fresh $(62 \%)$ and dry state (38\%).

Corrosion, both humic and fungal/bacterial (Figs. 2, 4), is arguably the most important alteration; it affects the surfaces of the majority of the analysed specimens with variable degrees of attack (30-100\%). In contrast, the teeth are genuinely preserved and were apparently impervious to the corrosive agent. Many specimens have a very invasive (probably bacterially mediated) manganese coating. Various remains also show disturbance by plant roots. On the other hand, very few specimens are weathered and to very limited degree (up to stage 2 sensu Behrensmeyer 1978). None of the remains show evidence of mechanical abrasion/polishing or scratching; trampling evidence is virtually absent, it was found only on $1.53 \%$ of the suid bones.

In addition to the remains of dogs, bears and badgers, the presence of carnivores is also indirectly supported by bites, gnawing marks and rarer gastric corrosion observed on a sizeable number of specimens. Carnivore ravaging is particularly evident on various proximal and distal long bone epiphyses, as well as on mandibular rami; it was observed on $11.61 \%$ of cattle remains, on $20.78 \%$ of caprine specimens and on $15.27 \%$ of suid remains.

Human modifications have been observed on the remains of bovids and suids; they include intentional fractures $(22.31 \%)$, some with evidence of dynamic loading of force against the cortical surface and detachment of cone flakes. Various types of cuts were also recorded on 17\% of cattle remains, on $12 \%$ of caprine specimens, as well as on $12 \%$ of the suid material. Cut marks produced by humans were also found on a left coracoid of Anatidae.

A very low percentage $(0.59 \%)$ of fragments is charred, mostly from room E1 and subordinately from room $\mathrm{W} 1$. There are incompletely to completely incinerated specimens, 


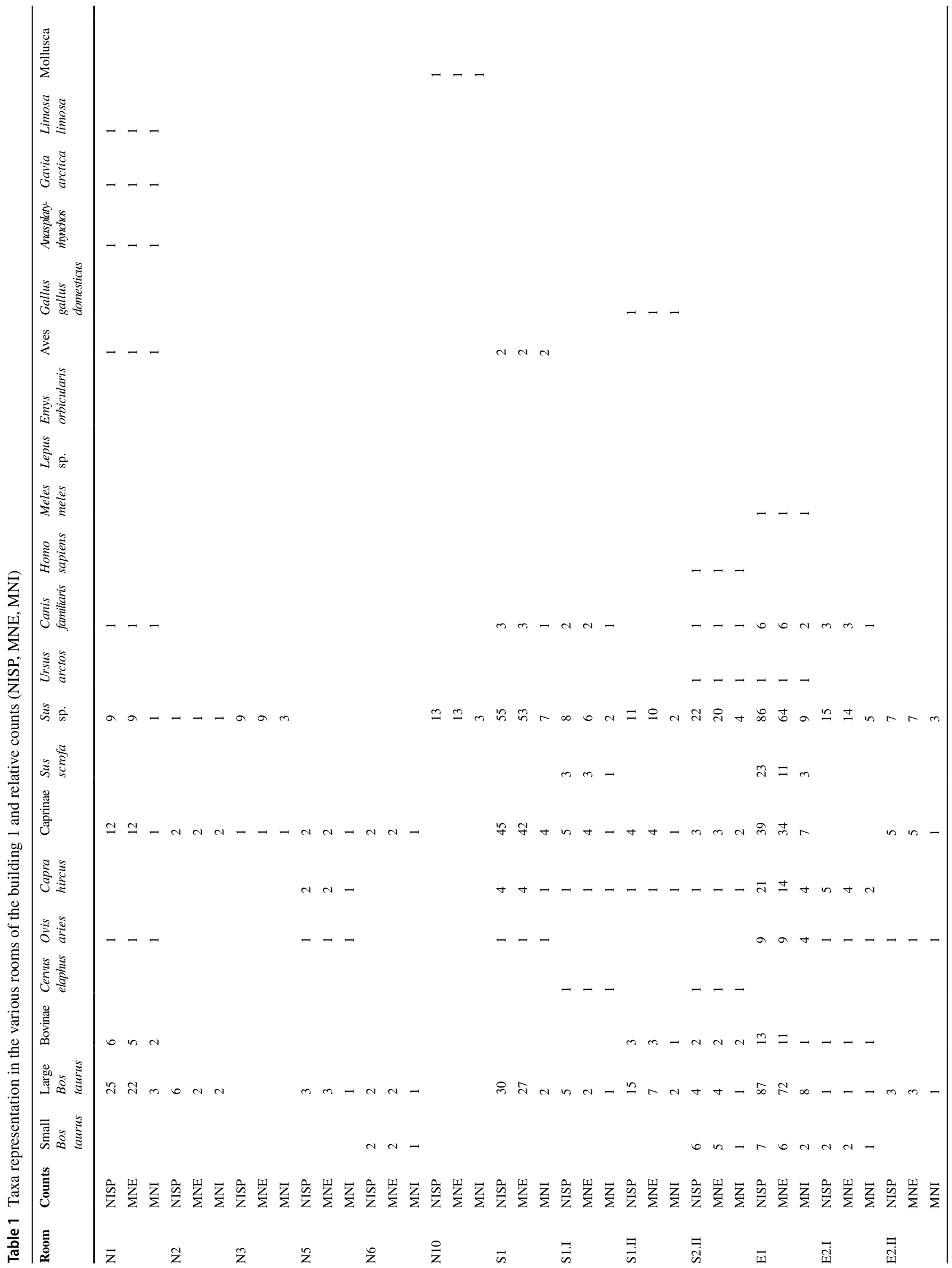




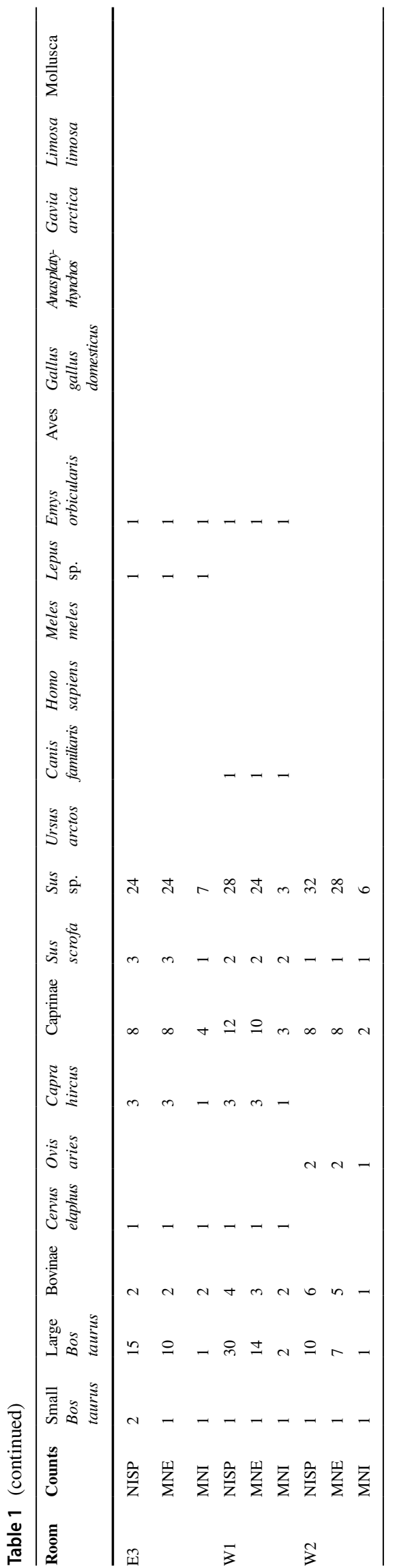

which range from blackened or dark brown in colour to bluish-violet and white.

\section{Carcass exploitation}

MNE counts of bovine remains from E1 (Fig. 5A-B) to W1 (Fig. 5E-F) relate positively and significantly $(\mathrm{rs}=-0.71$, $p<0.05$ in both cases) to their correspondent MGUI and sFUI values, with moderate density values. Sheep and goat remains from W2 (Fig. 5G-H) are characterized by high density and low nutritional value ( $\mathrm{rs}=-0.6, p<0.20$, whereas those from E1 (Fig. 5C-D) are associated with high nutritional values ( $\mathrm{rs}=-0.75, p<0.05$ ).

\section{Archaeobiological information}

The demographic structure of the archaeofauna is summarized in Fig. 6. Cattle, sheep and goats are mainly represented by adult individuals, with subordinate presence of sub-adults. Suids are dominated by young and sub-adult individuals. The canines represented in the studied samples indicate the presence of domestic pigs of both sexes; a few isolated canines belong unequivocally to wild boars. Other skeletal parts, unfortunately, are impossible to assign to either Sus domesticus or S. scrofa; hence, the relative percentages of the two taxa are impossible to assess.

\section{Discussion}

The results of this pioneer archaeobiological and taphonomic analysis of the Gonfienti archaeofaunas show that the bulk of the fauna is represented by domestic species and that wild taxa appear only represented by the red deer, brown bear, badger, hare and by a relatively varied avifauna, the latter mostly typical of fluvio-marsh environments. The simultaneous presence of large and small domestic cattle may indicate that different breeds were perhaps used for different economic purposes, as already supposed for earlier (e.g. Perusin and Mazza 2010) or contemporary (e.g. Cencetti et al. 2006) contexts of the Florence-Prato-Pistoia valley.

Based on the particular under-representation of their vertebrae and ribs (Fig. 3A-C) and the green-state fractures and the medium density and high nutritional value of their limb bones (Figs.5, 7A-H), the bovine remains from the rooms W1 and E1 are considered as meal waste. The same substantially applies to the caprine specimens from E1; in contrast, the sheep and goat specimens from room W2 show low nutritional values associated with high bone density and can thus be classed as butchery discards. The relatively high frequency of young and sub-adult suids in the mortality profiles of Fig. 6 indicates that these animals were likely processed for food, as most probably was the anatid whose 

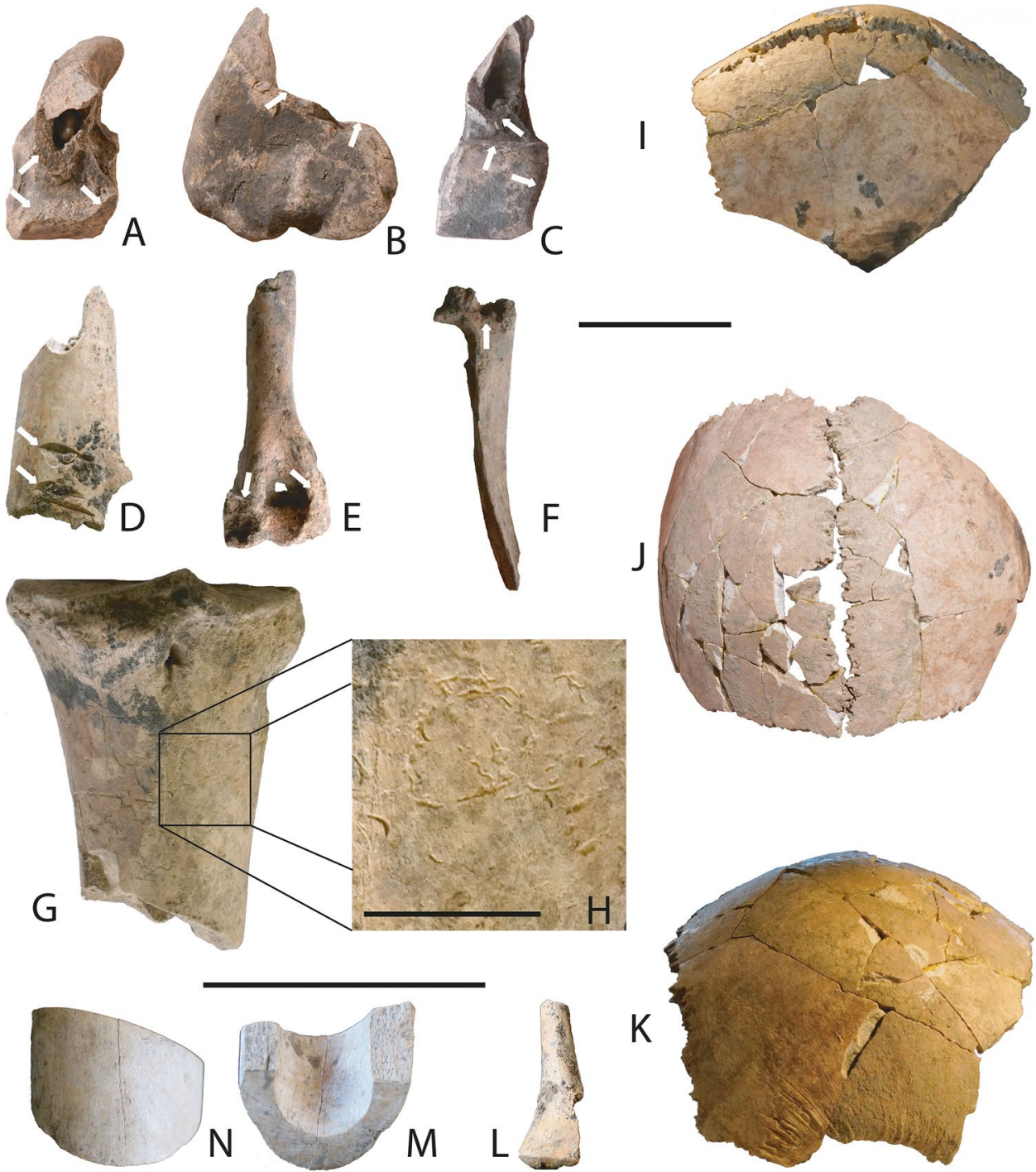

Fig. 2 Left humerus of small Bos taurus, medial fragment of distal epiphysis from US 1428, room W2, in proximal (A), medial (B) and cranial (C) views. White arrows indicate chopping marks. The specimen is largely encrusted with (probably bacterially-mediated) manganese dioxides; the coating does not affect the fracture surfaces. Fragmental diaphysis of bovine left femur (D) from US 1650, room E1, in medio-distal view; white arrows show three evident chopping marks. Distal half of suid right humerus (E) from US 1650, room E1, in caudal view; white arrows mark gnawing evidence. Proximal part of suid right ulna (F) from US 1650, room E1, in lateral view; the olecranon is gouged out, and tooth furrows (right arrow) are visible in the

coracoid displays a human-inflicted cut. Speculation can also be extended to include the domestic fowl and other anatid remains among the possible residues of food processing, in spite of the fact that these specimens show no sign of butchering, bites or combustion to support such a conclusion. In fact, the bird carcasses may have been used for other purposes, related, for instance, to the implementation of tools or ornamental items or to cult rituals; we cannot exclude that exposed cancellous bone. Proximal portion of left metacarpal bone of large Bos taurus in dorsal $(\mathbf{G})$ view; detail $(\mathbf{H})$ shows evidence of fungal/bacterial corrosion on the bone surface. Parietal bones of juvenile human skull from US 1055, room S2II, in left lateral (I), dorsal (J) and right lateral (K) view. Distal portion of foetal human humerus from US 1650, room E1, in cranial view $(\mathbf{L})$. Worked artefact obtained from long bone diaphysis from US 1626 A, room E1, in internal $(\mathbf{M})$ and external $(\mathbf{N})$ views. Upper and lower scale bars $5 \mathrm{~cm}$ : the former is relative to $(\mathbf{A}-\mathbf{F})$ and $(\mathbf{I}-\mathbf{K})$; the latter to $(\mathbf{G}$ and $\mathbf{L}-\mathbf{N})$. Scale bar for $(\mathbf{H}) 1 \mathrm{~cm}$

also the domestic fowl Gallus gallus domesticus was still more considered as a symbolic animal than as a source of food (Corbino et al. 2021). A further option is that the bird remains are in secondary context, transported and left over as the result of winnowing by running water after Edifice 1 had finally been abandoned, as is most probably the case with the scant bear and badger material. On the other hand, the wild boar, deer and hare remains could perhaps indicate 
Fig. 3 Observed versus MNIbased expected amounts of bones in (A) Bovinae, (B)

Caprinae and (C) Suidae.

There is a marked, systematic under-representation of axial bones, metapodial bones, and phalanges
A

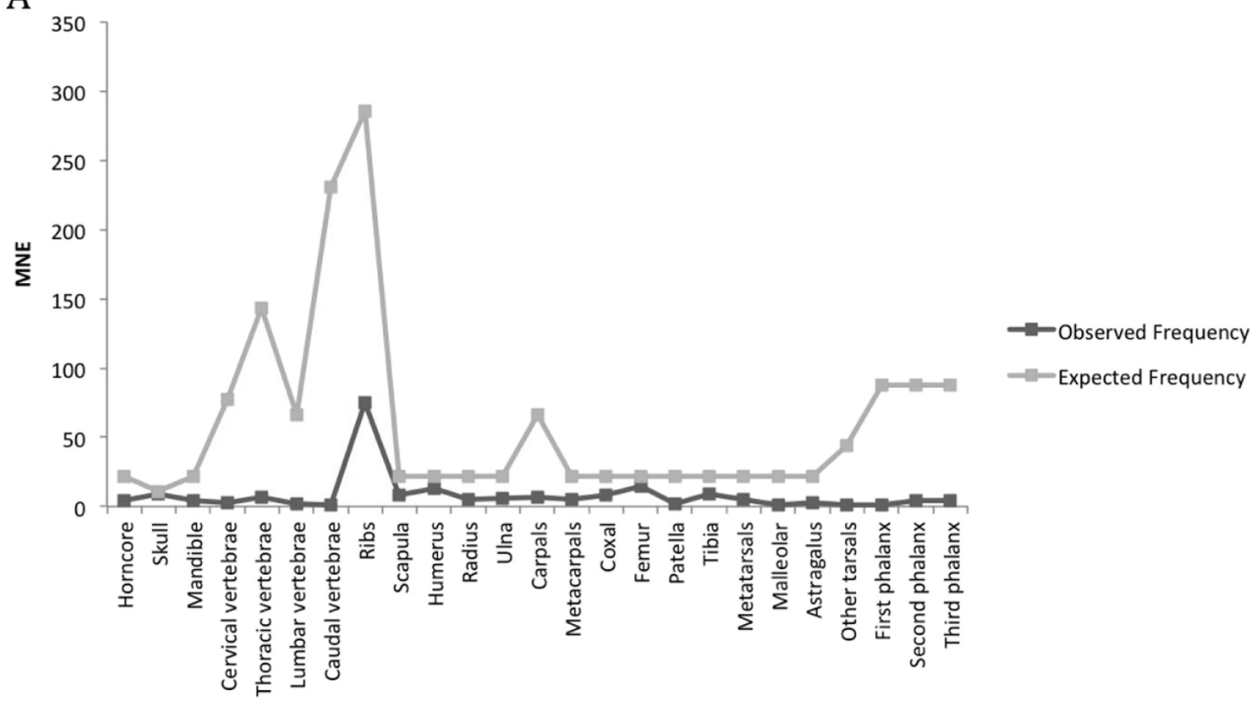

B

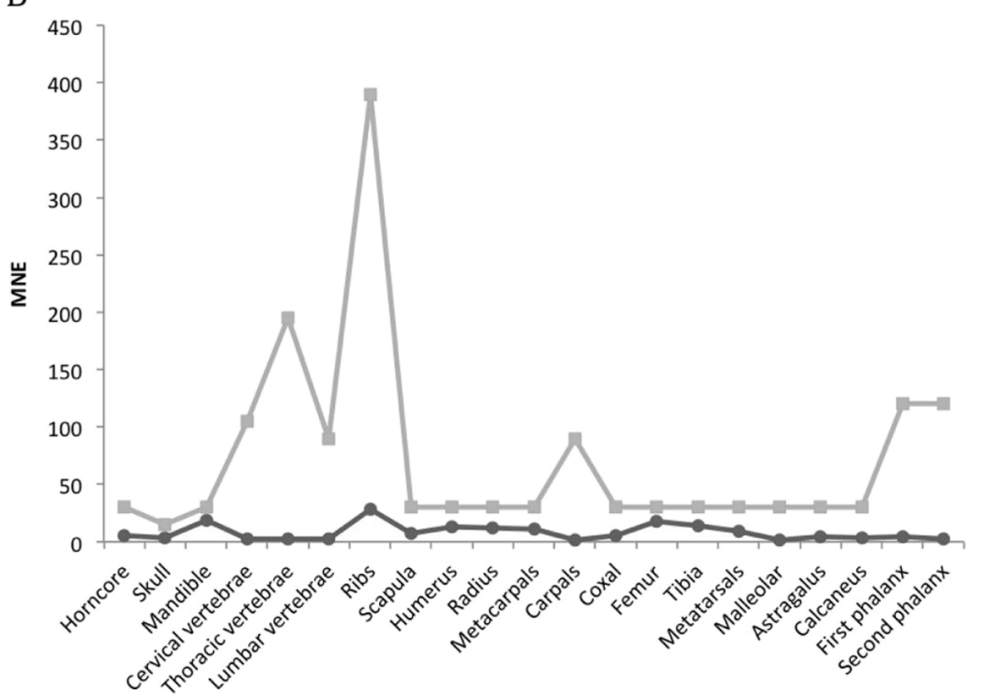

C

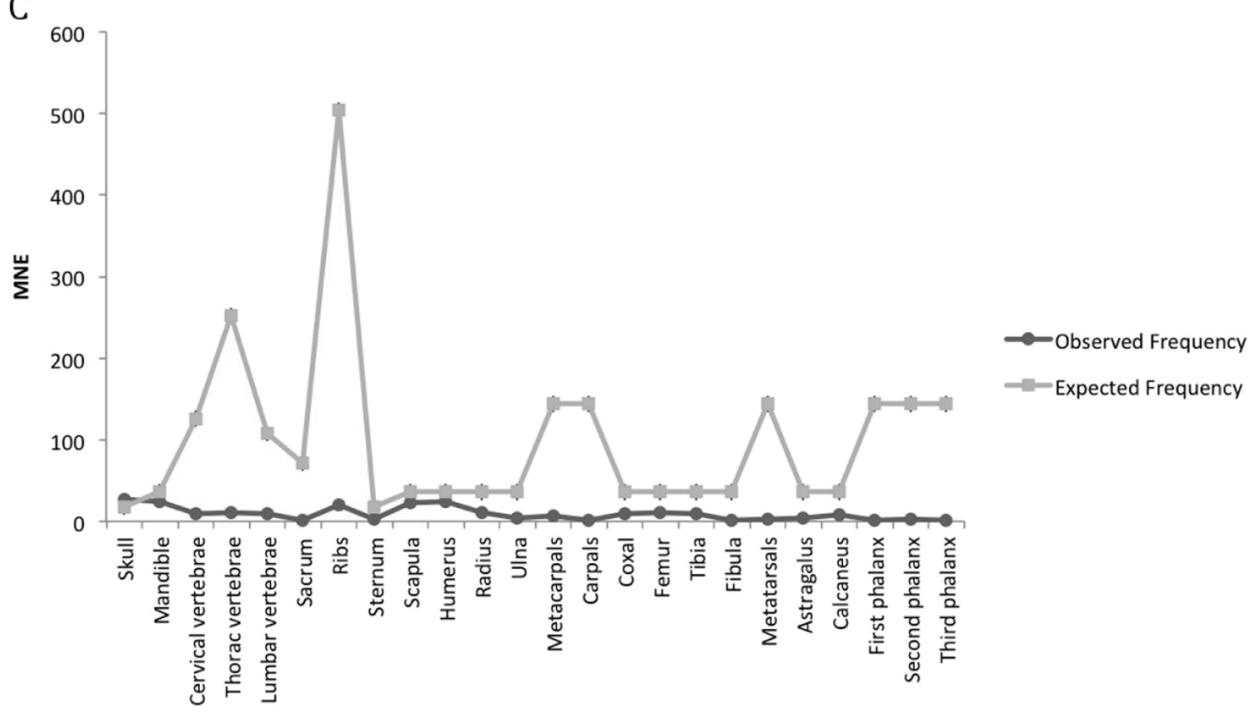




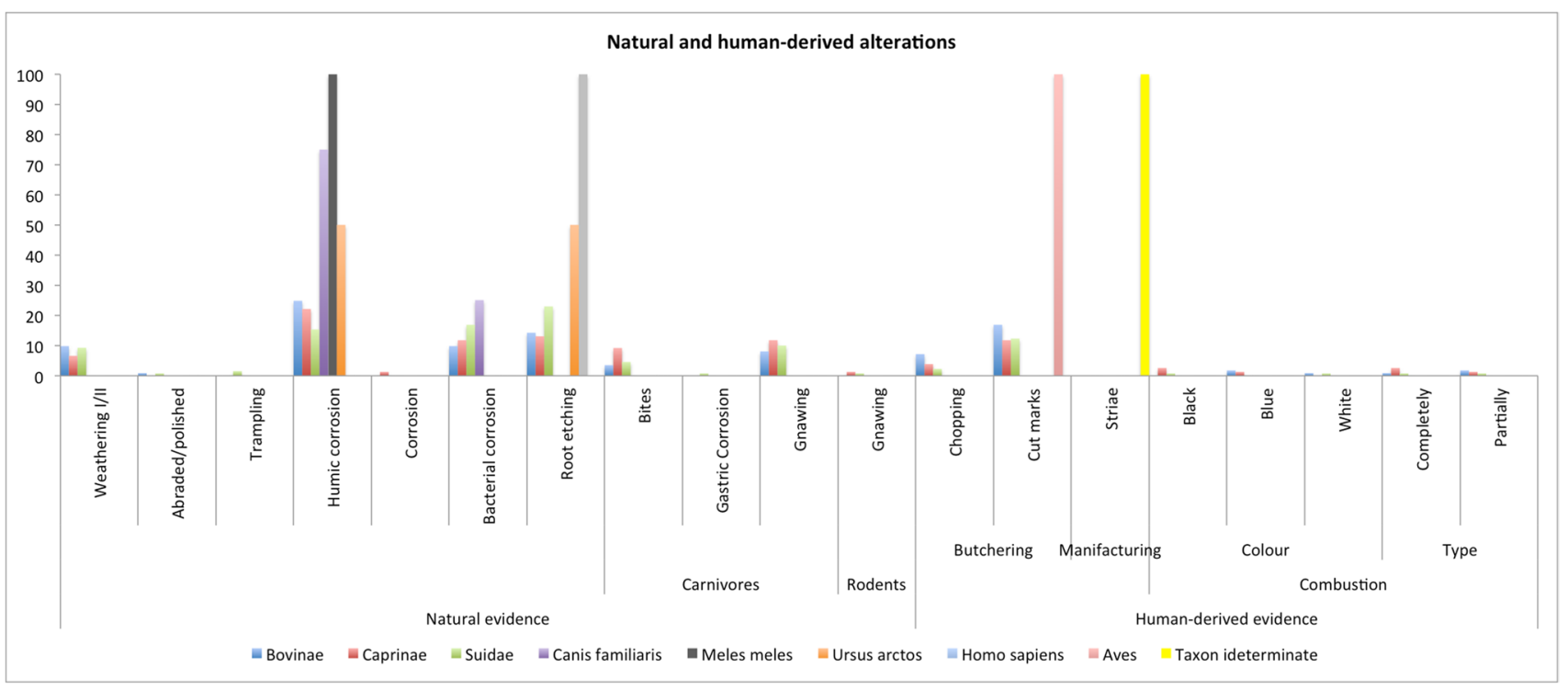

Fig. 4 Incidence of both human and non-human signatures. The surfaces of various specimens are affected by corrosion and root etching

that Etruscans included game in their diet, at least occasionally. These species were typical, prime hunting targets of the Etruscan people of the time (Camporeale 1984; Farello 1995, 2006; Cocomazzi 2008), and their presence may confirm what sources and figurative representations tell us about Etruscans' hunting skills.

The colours of the charred specimens from rooms E1 and $\mathrm{W} 1$, some of which calcined white, are compatible with exposure to high temperatures $\left(>650^{\circ} \mathrm{C}\right.$, Shipman et al. 1994) for short periods of time or with prolonged combustion at temperatures up to $500{ }^{\circ} \mathrm{C}$ (Karkanas et al., 2007), anyhow with heating to sustained temperatures that can only be reached and developed in kilns, ovens or furnaces, and not in campfires. Unless the food was cooked somewhere else and then taken to the house only to be consumed, which seems illogical, given the fact that animal carcasses were processed inside the building, as indicated by the W2 wastes, the presence of charred specimens confirms that Edifice 1 had a kitchen whereby animal chops were roasted.

Overall, the evidence suggests that the western area of Edifice 1, and in particular room W2 based on the results of the MGUI/sFUI-density comparisons (Fig. 5), was used for the preparation of meat for consumption. Room W2 was where kitchen waste was dumped and, presumably, where animal food was roasted in ovens capable of developing relatively high temperatures.

Once prepared, part of the food was consumed directly in the western wing, supposedly in room $\mathrm{W} 1$, and part in the eastern section of the structure, apparently in room E1. At least two scenarios can be theorized: (1) Edifice 1 was a permanently inhabited, residential building or (2) a place of special importance, used only on special occasions. In either cases, meals could have been (1) habitually consumed by householders in the western wing, in or near the kitchen area, and only occasionally in the eastern wing, which may have been used as a sort of boardroom for special guests or events, like banquets, possibly related to cult rituals, or (2) contemporaneously in two different areas of the building, both in or near the kitchen and in the more noble area, far from the kitchen fumes and, supposedly, bad odours, presumably by people of different social rank.

Mortality profiles like those depicted in Fig. 6, where aged cattle and caprine individuals appear to be particularly well represented, may also reflect a livestock husbandry objective that is not only meat, but that enhances services such as draft or burden bearing and products such as milk and wool. Unfortunately, the problem of sexing the remains makes it impossible to verify whether there was a sexually and ontogenetically determined selection of the bovids to be slaughtered, whereby cattle of both sexes were kept to advanced age for milk, dairy products, workforce and reproduction, and, in contrast, late adolescent male caprines were raised just to puberty and then slaughtered, while females were kept much longer for reproduction, milk and wool.

The extensive corrosion of the bone surfaces and, at the same time, the absence of dental corrosion suggest that the specimens were exposed to alkaline conditions. If these were post-depositional or early-burial, diagenetic alterations, they may have been caused by seasonal changes in the position of the local water table. Unless Gonfienti's substrate hosted alkaliphiles (extremophilic microbes), as high $\mathrm{pH}$ is detrimental to normal cellular processes, the bacterial corrosion noted on the specimens should have occurred under aerobic conditions, in a pre-burial 
A

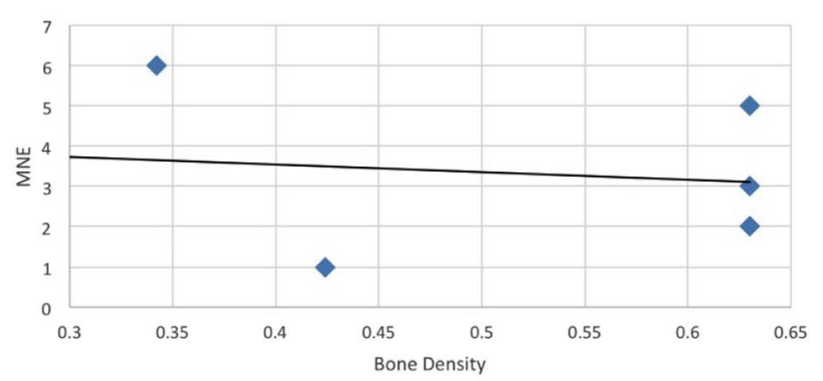

C

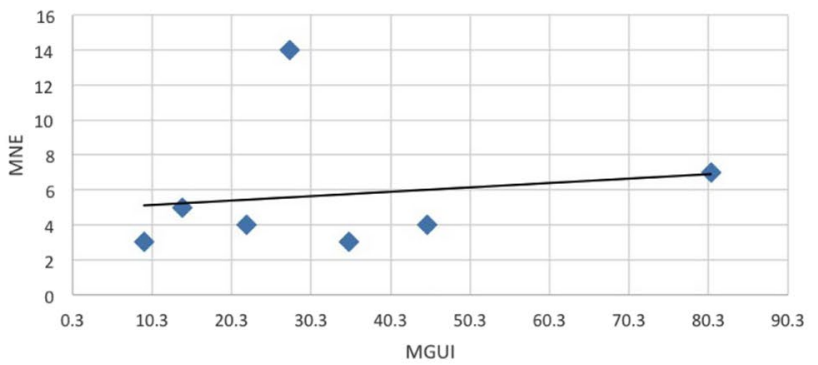

E

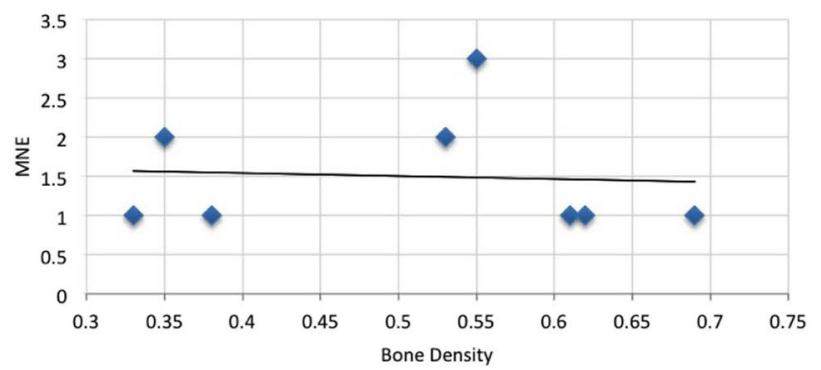

G

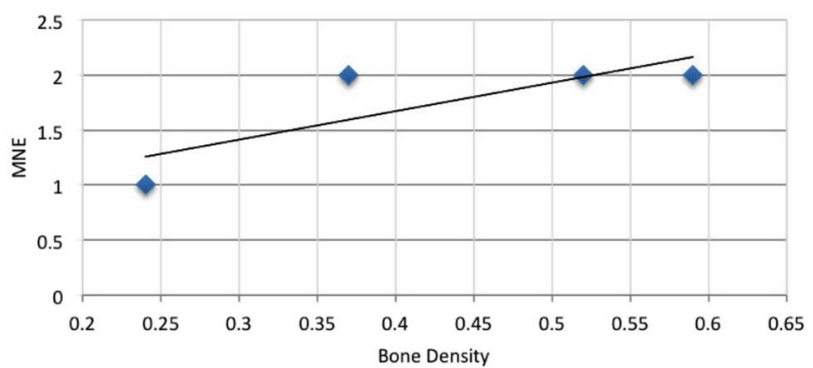

B

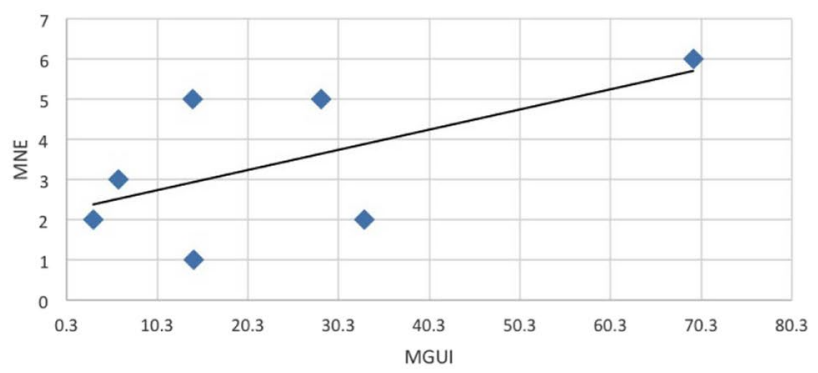

D

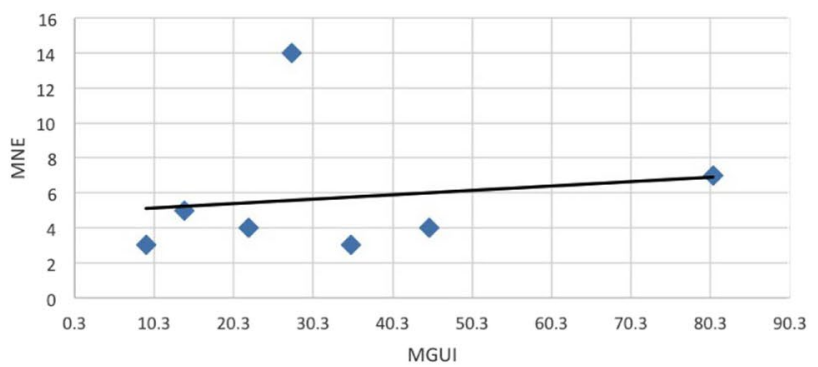

F

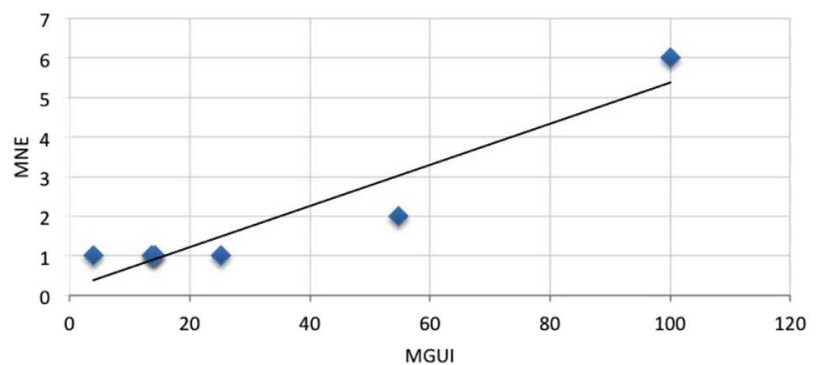

H

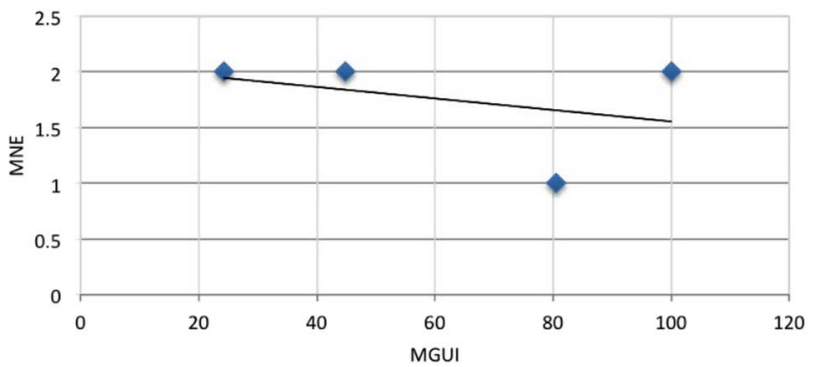

Fig. 5 Scatterplots of MNE values against density and MGUI values: A E1 Bovinae bone density; B E1 Bovinae MGUI; C E1 Caprinae bone density; D E1 Caprinae MGUI; E W1 Bovinae bone density; F W1 Bovinae MGUI; G W2 Caprinae bone density; H W2 Caprinae MGUI

or early post-burial stage. The coating of many of Edifice 1 's specimens with manganese oxides can be revealing in this regard. Insoluble manganese oxides form under oxic conditions; in aerobic water samples, microbially mediated manganese oxidation was experimentally observed at $\mathrm{pH}>7$ (Martin 2005; Kawashima et al. 1988). In sum, the manganese oxides on the bone surfaces at Gonfienti may have precipitated under aerobic, alkaline conditions by mediation of manganese oxidizing microbes.

Bacteria are often closely associated with plant roots, and actually, the presence of plant root erosions on various finds from Edifice 1 is strong evidence that the bone remains 


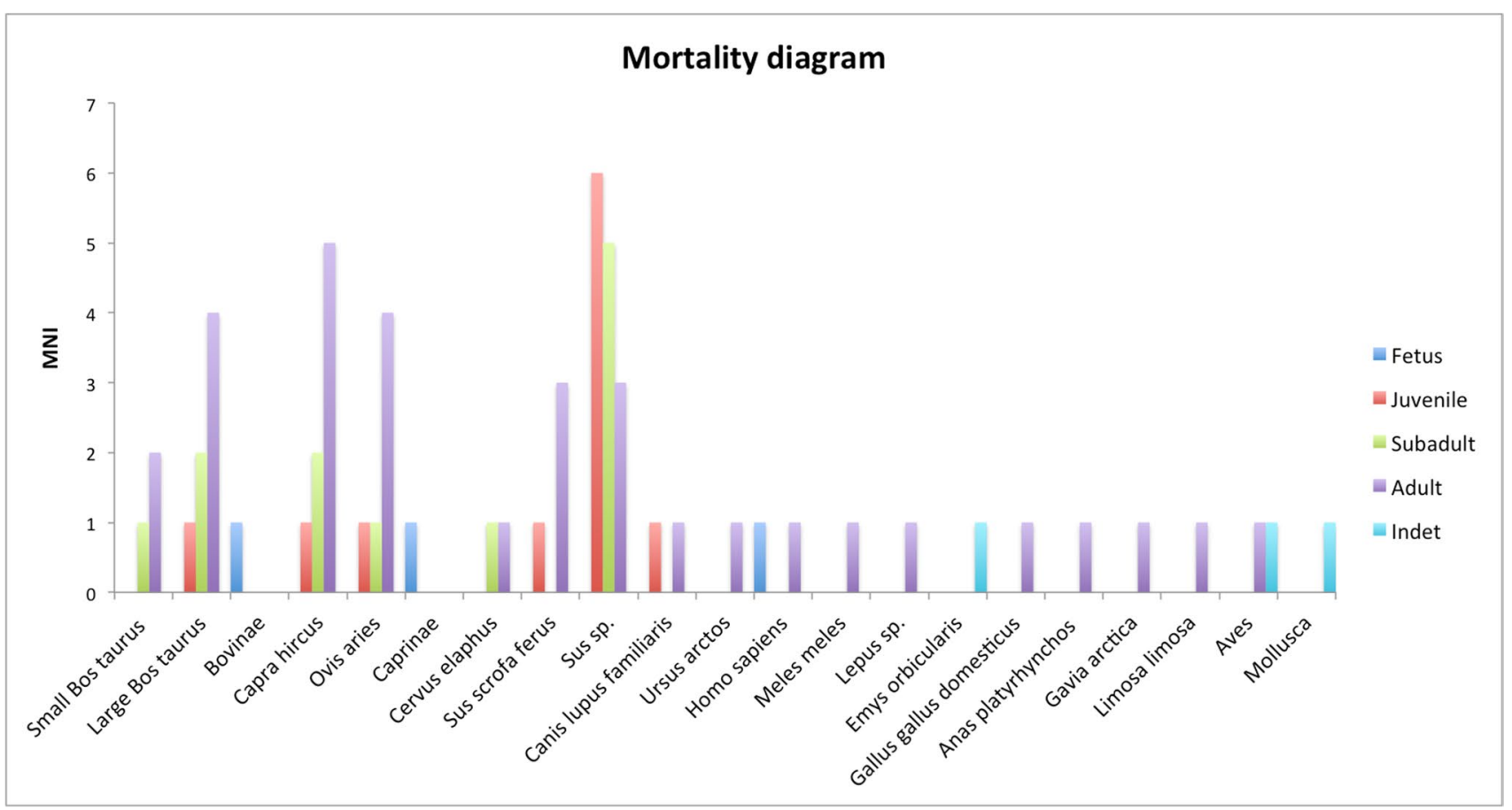

Fig. 6 Demographic structure of the Gonfienti archaeofauna

lied for a certain while, short after burial, within the upper, organic-rich and well-aerated soil layer.

Finally, a few words about the presence of the human bone fragments (Fig. 2). The three specimens are light, two of them are flat and the third one is rod-like; all three, therefore, are highly susceptible to winnowing. Thus, we cannot exclude that they were possibly removed from some nearby burial and introduced into Edifice 1 by streaming water, perhaps soon after the building was definitively abandoned.

\section{Conclusion}

The archaeobiological and taphonomic analysis conducted on the animal remains from Gonfienti's Edifice 1 provides us both a snapshot on the building's daily household life, but also both a local- and landscape-scale look at the context in which the structure was located. Various lines of evidence indicate that the west wing of Edifice 1 was used as a kitchen. It was perhaps equipped with an oven-like hearth; this was where animal carcasses were processed, butchering waste was discarded and more nutritious carcass parts roasted. Beef, but especially sheep, goat and pig, the latter largely slaughtered at young age, were the favourite items in the menu list. The meals were supposedly consumed in two separate wings of the building, one situated to the west, near the kitchens, and the other to the east; we can speculate that the former could have been the place for the servants, while the eastern wing was the more noble sector of the house that reserved for people of higher social status.

Whether the animals were raised in situ is impossible to say, at the moment, although the absence of structures that can be associated with barns and pigsties seems to rule it out. Hence, cattle, sheep/goats and pig carcasses were probably purchased somewhere in the vicinity of Edifice 1. However, the remains of individuals of advanced age and with work-induced bone pathologies suggest that animals were raised locally not only for meat, but also for other services and products, e.g. workforce, milk and wool.

The presence of dog remains inside a residential building is not so usual. Dog remains are a common occurrence in Etruscan sites, especially in the Etruscan-Padan ones of the mid-fourth and fifth centuries B.C. (Curci and Sertori 2019). Dogs were bred for utilitarian purposes, for company, hunting, protecting-guarding and sheep-herding. However, there is little evidence that they were kept inside the houses. Dog remains have sometimes been found in human graves, and there is clear evidence that dogs were involved in ritual practices; they were sacrificed for protection, purification, atonement or were possibly a worshipful offering to chthonic divinities such as Calu (De Grossi Mazzorin 2001). A parallel to Gonfienti's Edifice 1 is provided by the so-called Casa I, in Marzabotto (Bologna, Central Italy). Both were multipurpose buildings, which served as both residential quarters and areas for a variety of possible activities. Dog remains were found at both sites; the specimens from Marzabotto 
A

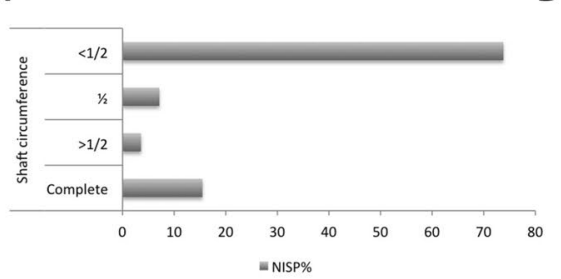

D

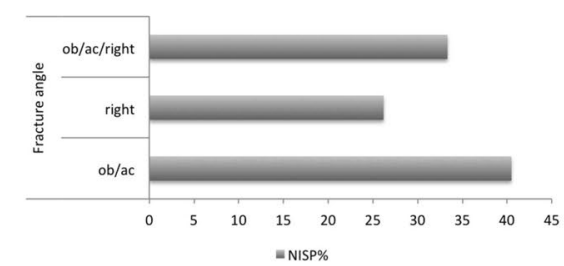

G

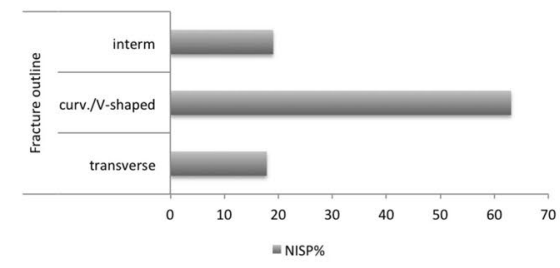

$J$

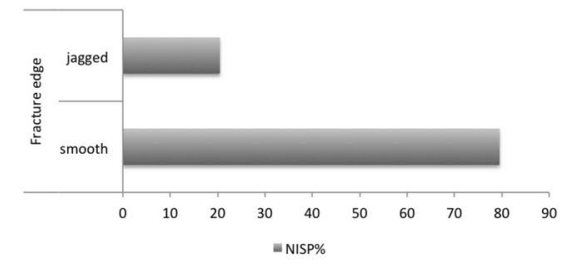

B

$\mathrm{H}$

K

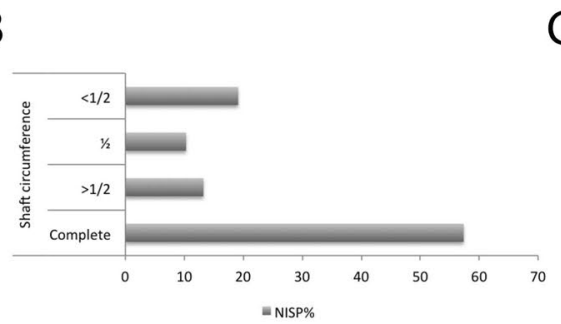

E
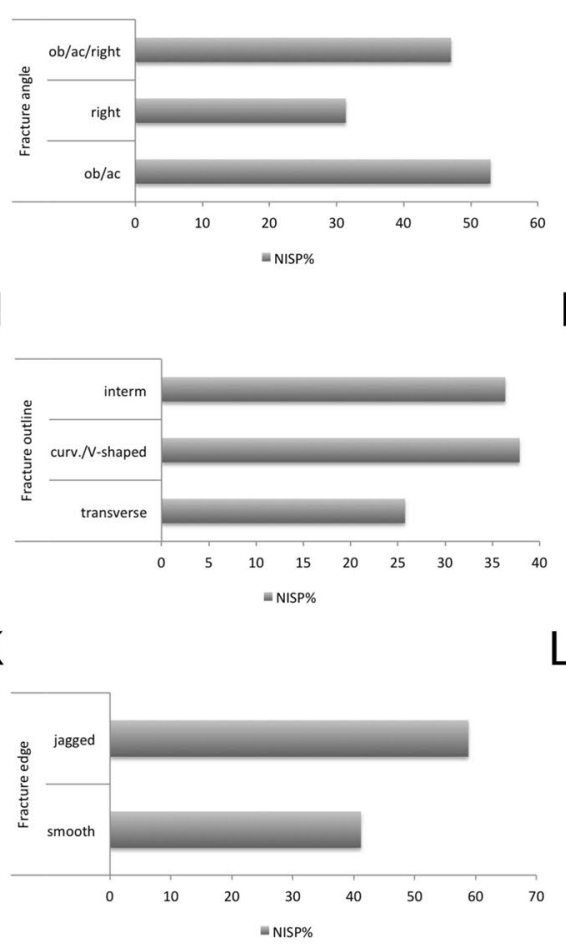

C

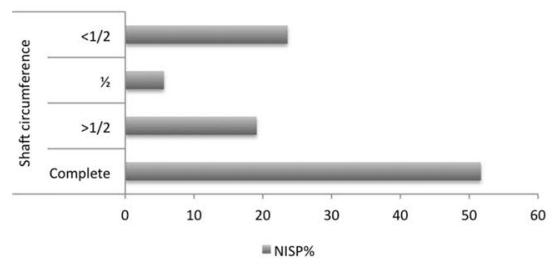

$\mathrm{F}$

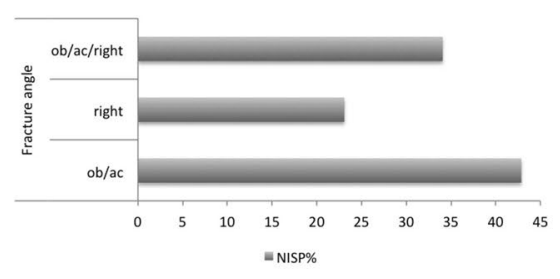

I

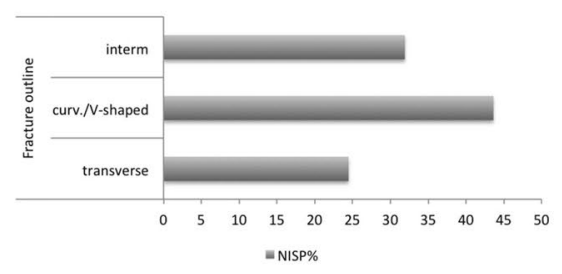

$\mathrm{L}$

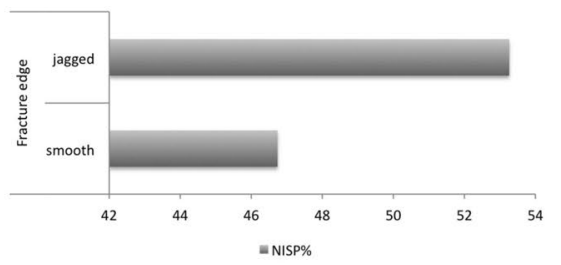

Fig. 7 Relative frequencies of the fracture angles, fracture outlines and fracture edges and completeness of the shaft circumferences: A Bovinae shaft circumference; B Caprinae shaft circumference; $\mathbf{C}$ Suidae shaft circumference; D Bovinae fracture angle; E Caprinae

show butchery marks suggesting that the animals were processed for meat. So far, there is no circumstantial evidence that there was cynophagy at Gonfienti, but it cannot be completely ruled out.

The wild animal remains from Edifice 1 may indicate that the householders supplemented their diet with meat from game animals. However, we cannot exclude that the finds are in secondary context, winnowed by water after the building was abandoned, as is most likely the case for the bear, badger as well as for the human remains retrieved from the site.

Phreatic seepage from movements of the water table into the sediments wherein the remains were buried could account for the extensive corrosion that affects the cortical surfaces of the bones from Edifice 1. From many sources, we know that the area was often waterlogged and that networks of ditches kept being made through time to drain fracture angle; F Suidae fracture angle; G Bovinae fracture angle; $\mathbf{H}$ Caprinae fracture angle; I Suidae fracture angle; J Bovinae fracture edge; K Caprinae fracture edge; $\mathbf{L}$ Suidae fracture edge

the oversupply of water (Poggesi et al. 2006). This is also reflected by the bird community, the bulk of which is dominated by waterfowl species. Very humid conditions prevailed in Edifice 1's final days; the area ultimately turned into a wetland. In fact, increased rainfall is reported between the sixth and fifth centuries BC in the area of Pisa by Kaniewski et al. (2018), therefore downstream from Gonfienti. According to the results of Kaniewski et al. (2018) study, but also to those of Andreotti (1999), an arid episode in 1200 BC caused marine transgression as a consequence of reduced fluvial influx from the hinterland. This episode was followed by a progressive increase in river flow up to about $200 \pm 30$ $\mathrm{BC}$, when a protected lagoon developed in the area of Pisa, which the Romans transformed into the Portus Pisanus. Increase river flow to the area of Pisa means increased rainfall in the hinterland and thereby a rise in the aquifer levels 
in the drainage basins located upstream, which is perfectly coherent with the sedimentary and archaeofaunal signals from Gonfienti's Edifice 1.

Supplementary Information The online version contains supplementary material available at https://doi.org/10.1007/s12520-021-01436-8.

Acknowledgements The authors are grateful to Dr. Gabriella Poggesi for inviting them to study the faunal remains in her care: this study would not have been possible without her foresight and personal generosity. Thanks are also due to Dr. Giovanni Millemaci and Dr. Lucia Pagnini for their feedback and observations. Fruitful discussions with Prof. Luca Cappuccini in an early stage of this work are gratefully acknowledged.

Author contribution The authors contributed equally to the study, read and approved the final manuscript.

Funding Open access funding provided by Università degli Studi di Firenze within the CRUI-CARE Agreement. This work was supported by the PAULMAZZARICATEN21-Mazza P. Fondo Ateneo 2021 MIUR (the Italian Ministry of Education, University and Research) grants.

Availability of data and material Data available.

\section{Declarations}

Conflict of interest The authors declare no competing interests.

Open Access This article is licensed under a Creative Commons Attribution 4.0 International License, which permits use, sharing, adaptation, distribution and reproduction in any medium or format, as long as you give appropriate credit to the original author(s) and the source, provide a link to the Creative Commons licence, and indicate if changes were made. The images or other third party material in this article are included in the article's Creative Commons licence, unless indicated otherwise in a credit line to the material. If material is not included in the article's Creative Commons licence and your intended use is not permitted by statutory regulation or exceeds the permitted use, you will need to obtain permission directly from the copyright holder. To view a copy of this licence, visit http://creativecommons.org/licenses/by/4.0/.

\section{References}

Andreotti A (1999) Il Bacino del Bientina in età etrusca: paesaggi e risorse. In: Andreotti A, Ciampoltrini G (eds) Gli Etruschi del Bientina. Storie di comunità rurali fra $\mathrm{X}$ e $\mathrm{V}$, Buti. Emme \& Emme, Comune di Bientina, pp 13-26

Behrensmeyer AK (1978) Taphonomic and ecologic information from bone weathering. Paleobiology 4:150-162

Binford LR (1978) Nunamiut Ethnoarchaeology. Academic Press, New York

Binford LR (1981) Bones: ancient men and modern myths. Academic Press, San Diego

Bocci E, Poggesi G (2000) Prato-Gonfienti: la ricerca archeologica nell'area dell'Interporto. In: Bettini MC, Poggesi G (eds) Archeologia 2000. Un progetto per la provincia di Prato. Atti della Giornata di studio (Carmignano, 29 aprile 1999), Montespertoli, pp $58-59$
Braun DR, Pobiner BL, Thompson JC (2008) An experimental investigation of cutmark production and stone tool attrition. J Archaeol Sci 35:1216-1223

Camporeale G (1984) La caccia in Etruria, vol 1. Giorgio Bretschneider, Rome

Cencetti S, Mazza P, Chilleri F, Cozzini F (2006) Madonna del Piano (Sesto Fiorentino, Florence, central Italy) ox and dog: a case of intentional Iron Age inhumation. Geobios 39:328-336

Cilli C, Malerba G, Giacobini G (2000) Le modificazioni di superficie dei reperti in materia dura animale provenienti da siti archeologici. Aspetti metodologici e considerazioni tafonomiche. Boll Mus St Nat Verona 24:73-98

Cocomazzi FL (2008) L'alimentazione degli Etruschi. In: Cocomazzi FL, Meini R, Milano S, Perego LG, Torretta S (eds) Fler. Moderne riflessioni su antiche questioni, Milano, pp 5-31

Corbino CA, Mazzorin JDG, Minniti C, Albarella U (2021) The earliest evidence of chicken in Italy. Quat Int. https://doi.org/10.1016/j. quaint.2021.04.006

Curci A, Sertori R (2019) Il cane in Etruria Padana: usi domestici. In: De Grossi Mazzorin J, Fiore I, Minniti C (eds) Atti del $8^{\circ}$ Convegno Nazionale di Archeozoologia (Lecce, 2015), pp 297-306

David B (1990) How was the bone burnt? In: Solomon S, Davidson I, Watson D (eds) Problem solving in Taphonomy Tempus, 2, Anthropology Museum. University of Queensland, Queensland, Australia, pp 65-79

De Grossi Mazzorin J (2001) L'uso dei cani nei riti funerari. Il caso della necropoli di età imperiale a Fidene - via Radicofani. In: Heinzelmann M, Ortalli J, Fasold P, Witteyer M (eds) Römische Bestattungsbrauch und Beigabensitten. Internationales Kolloquium, Rome, 1-3 April 1998, Wiesbaden 2001, pp 77-82

Farello P (2006) Caccia, pesca e allevamento nell'Etruria padana dall'VIII al IV secolo a.C. In: Curci A, Vitali D (eds) Animali tra uomini e dei: Archeozoologia del mondo preromano. Atti del Convegno internazionale 8-9 novembre 2002. Studi e Scavi, Nuova serie 14. Bologna: Ante Quem, pp 97-109

Farello P (1995) L'Emilia dal VI e V secolo a. C.: caccia e allevamento. In: Atti del $\mathrm{I}^{\circ}$ convegno nazionale di archeozoologia, Rovigo 5-7 marzo 1993. Padusa Quaderni 1. Centro Polesano di Studi Storici, Archeologici ed Etnografici, Rovigo, pp 209-234

Grant A (1982) The use of tooth wear as a guide to the age of domestic ungulates. In: Wilson B, Grigson C, Payne S eds) Ageing and Sexing Animal Bones from Archaeological Sites. BAR British Series 109, Oxford, pp 91-108

Hambleton E (2001) A method for converting grant mandible wear stages to Payne style wear stage in sheep, cow, and pig. In: Millard A (ed) Archaeological Sciences 1997: Proceedings of Conference Held at the University of Durham, 2-4 September 1997. BAR International Series 939. Archaeopress, Oxford, pp 103-108

Haynes G (1983) Frequencies of spiral and green bone fractures on ungulate limbs bones in modern surface assemblages. Am Antiq 48:102-114

Ioannidou E (2003) Taphonomy of animal bones: species, sex and breed variability of sheep, cattle and pig bone density. J Archaeol Sci 30:355-365

Kaniewski D, Marriner N, Morhange C, Vacchi M, Sarti G, Rossi V, Bini V, Pasquinucci M, Allinne C, Otto T, Luce F, Van Campo E (2018) Holocene evolution of Portus Pisanus, the lost harbour of Pisa. Sci Rep 8(11625):1-14

Karkanas P, Shahack-Gross R, Ayalon A, Bar-Matthews M, Barkai R, Frumkin A, Gopher A, Stiner MC (2007) Evidence for habitual use of fire at the end of the Lower Paleolithic: site-formation processes at Qesem Cave, Israel. J Hum Evol 53:197-212

Kawashima M, Takamatsu T, Koyama M (1988) Mechanisms of precipitation of manganese (II) in Lake Biwa, a fresh water lake. Water Res 22:613-618 
Lemoine X, Zeder MA, Bishop KJ, Rufolo SJ (2014) A new system for computing dentition-based age profiles in Sus scrofa. J Archaeol Sci 47:179-193

Lyman RL (1994) Vertebrate Taphonomy. Cambridge University Press, Cambridge

Martin ST (2005) Precipitation and dissolution of iron and manganese oxides. In: Grassian VH (ed) Environmental Catalysis. CRC Press, Boca Raton, pp 61-81

Metcalfe D, Jones KT (1988) A reconsideration of animal body-part utility indices. Am Antiq 53:486-504

Millemaci G, Pagnini L (2011) Gonfienti II, Lotto 14, Edificio 1. In: Carta archeologica della provincia di Prato dalla Preistoria all'età romana. Borgo San Lorenzo, pp 309-355

Payne S (1973) Kill-off patterns in sheep and goat: the mandibles from Aşvan Kale. Anatolian Stud 23:281-303

Perazzi P, Millemaci G, Pagnini L, Pallecchi P, Fonzo P (2011) Gonfienti, area dell'Interporto della Toscana Centrale. In: Perazzi P, Poggesi G (eds) Carta archeologica della provincia di Prato dalla Preistoria all'età romana. Borgo San Lorenzo, pp 309-355

Perusin S, Mazza PPA (2010) Semitella, an Italian Bell-Beaker (Final Copper Age) animal burial ground. J Archaeol Sci 37:737-757

Poggesi G, Donati L, Bocci E, Millemaci G, Pagnini L, Pallecchi P (2005) Prato-Gonfienti: un nuovo centro etrusco sulla via per Marzabotto. In: Govi E, Sassatelli G (eds) Culti, forma urbana e artigianato a Marzabotto. Nuove prospettive di ricerca. Atti del Convegno di Studi di Bologna, S. Giovanni in Monte, 3-4 giugno 2003, Bologna, pp 267-300

Poggesi G, Pallecchi P, Bocci E, Millemaci G, Pagni L (2006) PratoGonfienti. Interporto della Toscana Centrale: gli interventi nell'area dell'insediamento etrusco. Notiz Soprint Beni Archeol Toscana 2, Florence:68-75

Poggesi G, Bocci E, Millemaci G, Pagni L (2007) Prato-Gonfienti. Interporto della Toscana Centrale: lo scavo dell'edificio del lotto
14 e gli interventi nell' area dell'insediamento etrusco. Notiz Soprint Beni Archeol Toscana 3, Florence:112-116

Poggesi G, Bocci E, Pagnini L, Lo Schiavo F (2011) Rapporti fra l'Etruria settentrionale interna e il territorio di Capua. I kyathoi con anse a corna tronche e cave. In: Gli Etruschi e la Campania Settentrionale, Atti del XXVI Convegno di Studi Etruschi Italici (Caserta, Santa Maria Capua Vetere, Capua, Teano 2007), PisaRome, pp 167-180

Poggesi G (2013) Area archeologica di Gonfienti: edificio residenziale del Lotto 14. Notiz Soprint Beni Archeol Toscana 9, Florence:221

Reitz EJ, Wing ES (2010) Zooarcheology. Cambridge Manuals in Archaeology, Cambridge

Rowley-Cowney P, Halstead P, Collins P (2002) Derivation and application of a Food Utility Index (FUI) for European wild boar (Sus scrofa 1.). Environ Archaeol 7:77-87

Shipman P (1988) Actualistic studies of animal resources and hominid activities. In: Olsen SL (ed) Scanning Electron Microscopy in Archaeology. British Archaeological Reports, International Series 4, Oxford, pp 261-285

Shipman P, Foster G, Schoeninger M (1984) Burnt bones and teeth: an experimental study of color, morphology, crystal structure and shrinkage. J Archaeol Sci 11:307-325

Symmons R (2005) New density data for unfused and fused sheep bones, and preliminary discussion on the modeling of taphonomic bias in archaeofaunal age profiles. J Archaeol Sci 32:1691-1698

Villa P, Mahieu E (1991) Breakage patterns of human long bones. J Hum Evol 21:27-48

Publisher's note Springer Nature remains neutral with regard to jurisdictional claims in published maps and institutional affiliations. 